\title{
A Disenchanted View of Organized Crime: Mafia, Personalized Networks and Historical Legacies
}

\author{
Christian Giordano \\ Department of Social Anthropology, University of Fribourg (Switzerland)
}

\begin{abstract}
For a long time the Mafia was considered an anti-modern phenomenon that would have come to an end with society's evolution. Contrary to this expectation, the Mafia proved to be far more resilient, so much so that it responded effectively to the challenge of globalization. Analyses about the Mafia are often based on two myths, namely the folkloristic one and the pyramidal one. In the first one, the role of secret and occasionally gruesome rituals with an archaic aura has been voyeuristically played up, whereas the second one views the Mafia as a centralized institution on a par with a state institution. This paper highlights, instead, how the Mafia has shown to be more modern than the State on account of its strategic use of personalized networks. The personalized and informal Mafia networks have proven to be far more efficient and well organized both in public mistrust societies, in which the Mafia finds its most favorable habitat to flourish, and in the vast context of globalization, where formal institutions have trouble establishing themselves and imposing their role due to structural reasons.
\end{abstract}

Keywords: Mafia, Personalized Networks, Patronage Coalitions, Informality, State Legality, Legitimacy, Public Mistrust, Violence

\section{INTRODUCTION: AN ENCHANTED VIEW OF THE MAFIA ENIGMA}

Ever since the Mafia was discovered in Sicily in the second half of the $19^{\text {th }}$ century, experts and non professionals have looked upon it as both a monstrous and fascinating indecipherable phenomenon. This enchantment, quite conspicuous among researchers (particularly among sociologists, jurists, and, in the past, physical anthropologists) and artists alike (writers and movie directors foremost), highlights a deep-rooted ethnocentric paradox, which, from the very beginning, has characterized the debate on this by now global social phenomenon.

The first aspect of this paradox may be summarized as follows: among Mafia experts, we can detect the opinion, at times implicit and often unconscious, that the Mafia is an obsolete manifestation, unworthy of modernity, and pertaining to dark ages connoted by social barbarism. According to this view, which, at least potentially, is certainly brought on by $18^{\text {th }}$ century rationalism, Mafia and quasiMafia phenomena are interpreted as a relic of a dying out archaic world.

In the meantime, we know full well that an optimistic evolutionist scenario is a far cry from reality. The fact that the Mafia in Palermo doesn't kill any more doesn't mean that it has been defeated or dismantled: it is only an indication that it no longer needs to resort to physical violence. Judges, police authorities, and some politicians committed in the anti-Mafia fight aptly point out that in Sicily, and particularly in Palermo, the Mafia is alive, flourishing and has nothing to fear any more. According to this disquieting remark, made on October 12, 2003 by Luciano Violante, former president of the Italian Chamber of Deputies, we must assume that at present the Mafia in Sicily can once again weave its political intrigues and manage its illegal economic enterprises without fearing the State's intervention - as instead occurred in the early nineties of the past century. Therefore, it doesn't need to revert to startling violent actions, since the Mafia kills personeeccellenti [high-ranking notables] only when it feels threatened by the public authority. What Luciano Violante said also means that the Mafia in Sicily has successfully managed to overcome the critical phase in which the State had waged war against it. If this forecast, which moreover had already been expressed in 2000 by the judge Ferdinando Imposimato from Palermo, is correct, then we can draw the conclusion that the Mafia is capable of reproducing itself and prospering even in late modernity (Imposimato 2000). 
At this point, we can introduce the second aspect of the paradox. Regretfully, experts have to admit once more that the Mafia is extremely resistant. In several representations and just as many discourses, the Mafia is likened to those singularly vicious viruses that, through their incessant mutations, are able to permanently endanger a human group's collective health. More specifically, in Sicily we can observe that over the years the State has fought against the Mafia by using several repressive strategies, yet we must also acknowledge that the Mafia has never been annihilated.

The paradox that mystifies experts and concurrently kindles their interest in the Mafia, can thus be expressed as follows: Mafia phenomena are manifestations that are regarded as archaic, yet they are able to reproduce themselves even in any type of modernity. There is a blatant contradiction in this view of the Mafia. In fact, if the Mafia has actually reproduced itself to this day, it cannot be regarded as a typical example of by now obsolete social organizations. At any rate, the Mafia cannot be construed as a relic, as in Edward B. Taylor's definition of this term.

Such a paradox, as the original meaning of this notion shows, is based on the mystified astonishment about a seemingly contradictory reality. This deceptive inconsistency is rooted, as Max Weber would state, in the ongoing confusion between the criteria based on value judgments and the scientific interpretation of facts. In other words, it lies in the discrepancy between the prevailing (and undoubtedly legitimate) eagerness to finally vanquish the Mafia and the frustrating sociological fact of its persistence that experts have to invariably face. However, staying perplexed about this paradox certainly doesn't help us to understand the Mafia nor why it is so resistant. In any case, this paradox could even be misleading since it is highly incorrect to think that the Mafia, as a socially relevant phenomenon, is on its way to extinction only because, at first glance, it may be construed as an organization whose structure and culture place it in premodernity's dark ages.

In this article therefore, we shall try to clear two aspects above all:

- The Mafia has specific socio-structural characteristics that further its reproduction and expansion in late modernity (or postmodernity, as the case may be).

- In Sicily and other areas of the world, at present the Mafia finds its raison d'être in the chronic lack of trust in everything public. Since it is a legacy of the past, distrust is a social production permanently reproduced in the present.

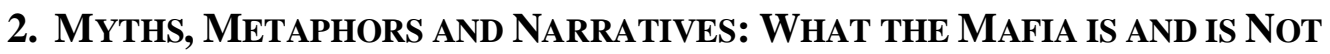

\section{The Folkloristic Myth}

According to this approach, Mafia and quasi-Mafia associations are reckoned as being practically identical to shady and undercover organizations or occult secret societies. Sicilian Mafia therefore is regarded as an emanation of a legendary secret fraternity, the notable and notorious Beati Paoli (also known as Beati di San Paolo), which, in the $17^{\text {th }}$ and $18^{\text {th }}$ century, excelled in applying its personal justice via threats or systematic recourse to physical violence against the ruling class' abuses of power and against the Spanish law's arbitrariness (Mühlmann, 1969; Giordano, 1992: 406). Moreover, the Mafia is compared if not assimilated to Masonic lodges or Carbonarism, i.e. those secret societies that drew inspiration from Giuseppe Mazzini during the Italian Risorgimento. Some experts would even have the term Mafia derive from this origin, as it would be the acronym of Mazzini autorizzafurti, incendi, avvelenamenti [Mazzini authorizes robberies, arsons, poisonings] (Hess, 1988:4). Such an argument of etymological nature, though rather bizarre, maintained some credibility until recently, probably because these acronyms were actually quite popular in the secret verbal codes of the Risorgimento. We need only mention the famous formula Viva Verdi, which was associated not only with the renowned composer involved in the struggle for Italy's independence and unity but was also a code for Viva Vittorio Emanuele Re d'Italia.

Such a representation of the Mafia, as this last example proves, in the end is a combination of exotic and orientalistic oddities. Thus, the Mafia is downgraded to a bizarre jumble of

- shady and occasionally gory initiation rites to confirm the candidate's admission in the association,

- mysterious ceremonies to certify and confirm ties of reciprocity, and

- specific friendship and kinship social practices to strengthen solidarity among members of the alleged secret societies (Alongi, 1887: 140 ff.; Cutrera, 1900:140 ff.; Hess, 1988: 106-110). 
Moreover, the folkloristic myth permanently refers to the existence of a specific Mafia-style attire and a secret phraseology and jargon.

However, the folkloristic myth cannot be dismissed as a bizarre collection of arbitrary fantasies of the authors who created it and made it popular. In all these representations of the Mafia, there is certainly a kernel of truth. Nevertheless, the voyeuristic overstatement of the covert or mysterious aspect and the fascinated exaltation of ritual and ceremonial oddities are both disturbing and misleading.

The case held in Palermo against former Italian prime minister Giulio Andreotti is a fitting example to illustrate how much the folkloristic myth can be deceptive and ultimately far from reality, even as regards to the fight against Mafia. It is a well-known fact that one of the key evidences of Andreotti's collusion with the Mafia, according to the prosecution, was a purported ritual kiss between the former prime minister and the Mafia boss Totò Riina, which should have been proof of the their strong bond of friendship. Such a by now world famous sign of alliance, recounted by the pentito di mafia [mafioso who has turned state's evidence] Balduccio Di Maggio when he testified before the investigating magistrate, was regarded as evidence of Andreotti's awareness of typical Mafia-style customs, and, consequently, as proof of his belonging to the onoratasocietà [honorable society]. Nowadays, Balduccio Di Maggio's statement, who on September 20, 1987, had not personally witnessed the ritual-like display of friendly affection between the former prime minister and the alleged capo deicapi [boss of bosses] of those days but had only heard about it in conversations with other Mafiosi, seems quite unreliable from a juridical viewpoint. Consequently, there has been a whole range of theories. According to Andreotti's entourage, it was a heinous Mafia fabrication to frame the former prime minister and place him in dire juridical trouble. According to Berlusconi's circle instead, invariably in dispute with the magistracy, the kiss between Andreotti and Totò Riina was the judges' own put-up affair. Both these explanations, clearly opportunistic since they serve a political means, are hardly tenable. However, especially in the latter conspiracy theory, one might wonder why the public prosecutor's office in Palermo didn't present credible proof, instead of hearsay evidence of an unlikely ritual kiss.

Yet, the reasons why a team of competent and experienced magistrates as those in Palermo gave so much relevance to a ritual-like action, though they should have been aware that, both from a juridical and a sociological viewpoint, it would have been quite difficult to prove, are amazing and quite puzzling. In my opinion, the bizarre and unfathomable tale about the kiss between Andreotti and Riina proves instead that the folkloristic myth, not only in literature and movies but also among the police and the magistrates, is still remarkably embedded in Mafia representations (Hess, 1988:108), though it is common knowledge that nowadays such ritual practices are sociologically highly unlikely.

In this case as well, we can perceive the enchanted view's consequences. In fact, ever since Italy's Unity (1860), i.e. when Mafia was so to speak discovered, police, the law, and the press have always stressed the aberrance of the Mafia phenomenon through the unmistakable overstatement of deviant characteristics and/or the most gruesome specificity. This was carried out so that both the honorable society's apparently unfathomable behavior and its unyielding cohesion could become more plausible for themselves and the Italian and Sicilian public opinion. Thus, the folkloristic myth was produced even thanks to eloquent and imaginative prosecuting witnesses (Hess, 1988: 107), and, over a period of 150 years, was reproduced, reconfirmed, strengthened, and modified, but never totally dismissed. The paradoxical fact is that the main producers and users, among whom there are also very conscientious and highly qualified representatives of the law, are prey to their own construction.

Due to exoticization and orientalization, the folkloristic myth of the Mafia in the end has created an artificial alterity (Giordano, 2001: 44) that has provided it with unique and practically unlimited characteristics. Thus, the Mafia boasts a quasi-numinous aura in which fearsome and horrific are suitably linked to intriguing and vigorous. The folkloristic myth spread by Mafia's enemies has turned into one of its trumps. In fact, the Mafia has been fully able to exploit it, especially to increase its influence, better its image, and strengthen its actual authority over a population that is quite skeptical about all public institutions.

\section{The Pyramid Myth}

This representation is based on the belief that the Sicilian Mafia and corresponding phenomena in Italy, Europe, and around the world, are monolithic, centralized, and rigidly structured organizations. Thus, Mafia associations are characterized by strongly hierarchic pyramid structures. As associations, 
they involve a vertical chain of various formally defined ranks and roles. At the top is the thus termed cupola (i.e. the Mafia's government) with the capo deicapi. The intermediate rank consists of a socially differentiated stratum of sottocapi [deputy chiefs], while, according to this pyramid model, the manovali [unskilled workers] who carry out what are regarded as the less prestigious and dirty work are at the bottom. Giuseppe Fava, the Sicilian journalist who was killed in 1984, likewise drew an organizational distinction within three levels. The Mafia could be separated into a first level consisting of killers, a second level of thinkers and planners, and a third one, the highest, consisting of politicians (Fava, 1983: $27 \mathrm{ff}$.).

Now, if we analyze these representations more in detail we will notice that the Mafia, according to the pyramid metaphor, displays structural analogies with the organization of modern States. Thus, through this metaphor, the impression is that the Mafia has been set up in accordance with the territorial State's model. Accordingly, the Mafia seems a sort of anti-State, which, in the end, turns out to be the mirror image of the State itself.

It is common knowledge that the empirical evidence of the above metaphor has been lacking until now. Italian police and legal authorities that have dealt with juridical institutes such as associazione di malfattori [association of malefactors] and associazione per delinquere [criminal association] have never been able to prove the existence of fixed organizational structures within Mafia groups. This is certainly one of the reasons why several Mafia bosses in the past have been able to get off with acquittals on the grounds of lack of evidence. The fight against Mafia in Sicily and Southern Italy suddenly became more efficient at the time of public prosecutors Giovanni Falcone and Paolo Borsellino, i.e. when the paradigm of a pyramid Mafia organization, due mainly to their remarkable competence and insight, was relativized, and the far more flexible notion of associazione per delinquere di stampomafioso [Mafia-like criminal association] was introduced in the juridical apparatus. Practically, the fact that the Mafia has specific structures that are unlike those of other types of organized crime was acknowledged. Therefore, the explanatory strength of the Mafia as an organized pyramid-like entity mirroring the State and in direct opposition to it turned out to be quite questionable, both from the viewpoint of criminalistic practice and the theoretic-scientific one.

However, we must admit that the pyramid metaphor is very convenient because apparently, do to its likeness with the State, it takes on a more familiar and therefore less mystifying aspect. Concurrently, this metaphor embodies an ethnocentric prejudice that proved fatal or at least a hindrance for criminalistic efficiency. We are talking about the typical Western modernity belief that a given organization, in order to be efficient as in the case of Mafia, must definitely have a system of rationalbureaucratic institutions analogous or identical to those of a territorial State.

Finally, we might wonder whether the Mafia would have survived to this day had it actually been a bureaucratic-like and rigidly centralized organization. In fact, we ought to keep in mind that the Mafia invariably seems to be at least one step ahead of the State that fights it back. In order to survive, the Mafia must always be able to foresee the public powers' next move. Laying no claims to thoroughness or conclusive answers, we have formulated the following five questions that further challenge the pyramid metaphor's validity:

- Could the Mafia have infiltrated the State's political-bureaucratic institutions so extensively if its administrative apparatus were really as ponderous and immovable as the State's?

- Wouldn't the several irrationalities of rational bureaucracy, typical of modernity and already mentioned by Max Weber (Weber, 1956: vol. II, 577 ff.), have impaired the specific Mafia efficiency?

- Doesn't the Mafia need a more streamlined and changeable organizational structure that allows it to develop extremely flexible strategies that anticipate the State's actions and help conceal its own illegalities?Giovanni Falcone had perceived this fundamental question with great insight when he wrote, "My greatest worry is that the Mafia is able to stay one step ahead of us."(Falcone, 2005:121)

- If the Mafia, as the pyramid metaphor suggests, were really a close-knit bloc, why do bloody conflicts that take on the aspect of actual Mafia wars lasting years on end constantly flare up?

- If the Mafia actually were solely a type of anti-State, mirroring a modern State, would it have been able to turn so quickly into a series of transnational-like global phenomena, as, for example, the case of ecology Mafia with its supranational business activities seems to be? 


\section{The Network Metaphor}

This representation of Mafia, which was developed chiefly by sociologist Henner Hess (Hess, 1988: $82 \mathrm{ff}$.), may be regarded as the most convincing attempt to invalidate the various explicative approaches we have introduced, particularly the pyramid metaphor. According to the network metaphor, the Mafia to all appearances is an association that is indeed hierarchic but also loosely structured, scarcely formalized, and, above all, non-centralized. Therefore, it appears to be a very complex social entity resembling a net-like system of temporary and flexible coalitions. These Mafia groupings are permanently characterized by their being created, broken up, and, in case, recreated according to the changing social situations and personal circumstances. In his analysis, Hess shows that the classic Sicilian Mafia associations, particularly the cosca (which in Sicilian dialect literally means artichoke leaf: in other words, the tough core surrounding the Mafia's uomo di rispetto [respected man]) and the partito (the mafioso's system of long-term social relations including his relations with public power representatives, i.e. politicians, magistrates, and bureaucrats in general) from a structural point of view are not a social group in terms of sociology. Therefore, the essential formal elements (statutes, official ranks and roles) are lacking in the Sicilian honorable society, as anywhere else, since Mafia associations consist of one or more networks in which pragmatic exchange relations are noticeable. To illustrate this structural specificity, we need only recall that particularly in Sicily (but even outside the island nowadays) the expression amici degli amici [friends of friends] is used in everyday parlance as a synonym of Mafia.

Social relations within such an evident plurality of Mafia networks are quite informal and extremely personalized, as the previously mentioned expression reveals. Essentially, there are three types of ties: family or kinship (including fictitious or ritual kinship), exploitable friendships, and the dyadic patron/client ones (Hess, 1988: 119-133; Giordano, 1992: 374-399).

However, we ought to draw a fundamental distinction with the help of two notions developed by Austrian historian Karl Kaser. In one kind of society, family and kinship solidarity are the keystone of social organization, while in the other, relations based on asymmetric and vertical protection (such as the dyadic relation between patron and client) are the backbone of the entire social structure (Kaser, 1995: 167 seq.; Kaser, 2001: 71 seq.). In the former type of society, therefore, such as in Albania (especially in the northern regions), there is a prevalence of clan groups, lineages, stock, and various kinds of extended family. In the latter type, as the case of Sicily shows, family and kinship structures are quite circumscribed and the nuclear family is the only grounds for every type of solidarity and trust. To broaden this very finite sphere of sociability, other types of personal ties are adopted in these societies, such as instrumental friendships and long term dyadic relations between patron and client. The different solidarity and trust structures have a strong influence on the specific make up of mafia networks. Thus, family and kinship ties will characterize the first type of society rather than the second type, in which clientelist relations will be far more significant.

Therefore, in the first case, as the example of Albania shows (which we analyzed through evidence gathered by the Federal Attorney Office of Switzerland), mafia networks currently seem to be relatively limited since they mirror the structures and rules of a patriarchal family (as corroborated by the report of Interpol deputy director Ralf Mutschge, dated December 13, 2000). As Cristina Maria Matei notes, analogous mafia structures based the family ties and the patriarchal kinship system are noticeable in the Caucasus area as well.

Conversely, in the second case, i.e. the Sicilian one, there are usually far more pervading Mafia associations since they are structurally similar to the well-known political sphere's clientelist organizations. In this case, the networks will be based on vertical and asymmetric ties; in other words, patron/client dyads defining dependence and power relations within the Mafia's fabric. This explains why the authority of the capimafia in these remarkably complex organizations is less formal, yet not less hierarchic than it was thought to be at first. Mafia power, as Diego Gambetta has convincingly affirmed, depends upon the leaders' transactional ability and specifically on the successful exchange of mutual services between bosses and subordinate members in the network (Gambetta, 1992: 48-53). Practically, if a person expects to maintain or reach a dominant role within a Mafia network, he must constantly prove to his henchmen that he can honor commitments and provide the necessary services even through threats of physical violence or its actual use. For this reason, Mafia bosses who are considered capable and worthy of being regarded as such by other network members are intrinsically, and contrary to plain patrons, violent entrepreneurs (Blok, 1974). 
Compared to the pyramid one, the network metaphor has obvious analytical advantages. The Mafia is conceptualized as an extremely flexible, variegated, and changeable reality and, above all, one that can adapt to new situations. As such, in case of open conflict with the State it can react by carrying out startling terrorist attacks, as well as expand, branch out, and diversify transnationally, as indicated also in the Europol 2000 annual report. In this context, we can specify the following two aspects:

- The Mafia, as a complex system of networks, doesn't necessarily have to be an anti-State or a State within the State. Mafia organizations instead can infiltrate the State's structures via the mobilization of network links. Thanks to these infiltration strategies, Mafia associations are able to probe, neutralize, and finally exploit specific people and institutions of the State's apparatus. Ferdinando Imposimato, public prosecutor in Palermo who worked on the anti-Mafia team with Falcone and Borsellino, has aptly stressed that the State and its representatives (politicians and public functionaries), as legal guardians of the monopoly over the use of force, become, almost inadvertently, accomplices of their own enemies (Imposimato, 2000). Between the legal State and the illegal Mafia there isn't a relation of mutual opposition but rather a shifting dialectic match which creates a situation of permanent and reciprocal interaction and interdependence. In this context, we must also add the existence of very peculiar discursive and ideological mutual ties between the State and the Mafia (Heyman and Smart, 1999: 11 ff.). If, on the one hand, the State needs a certain amount of Mafia to endorse its role as watchdog and custodian of social order, on the other hand, the members of Mafia networks try to justify their schemes and designs by stressing the absence and untrustworthiness of the State, which, by definition, is alien and indifferent.

- Thanks to its net-like and thus very flexible structure, the Mafia can easily sidestep national State boundaries and act very efficiently in global arenas. Consequently, it is able to take over and monopolize new illegal or criminal transnational markets. By now this phenomenon is noticeable not only in drug trafficking but also, for example, in the commerce of people (illegal immigration, prostitution, etc.), contraband of goods (works of art, weapons, raw materials, radioactive material, etc.), besides the transfer and disposal of all kinds of waste (see Europol annual reports).

Though in principle the most qualified authors (Blok, 1974; Hess, 1988; Gambetta, 1992; Varese, 2001; Mappes-Niediek, 2003) do not question the soundness of the network metaphor, we ought to voice some significant reservations that highlight the need for some revising and adjustments. Thanks to Italian sociologist Letizia Paoli, over the last years the network paradigm has been reexamined and improved, at least as far as the Italian case is concerned (Paoli, 2000). The author of 'Fratelli di Mafia', by analyzing the structural characteristics of cosa nostra in Sicily and the n'drangheta in Calabria, questions the fact that these Mafia associations are solely an aggregate of informal dyadic ties and coalitions. Her main argument, which moreover is quite convincing, highlights the fact that the Mafia, as a network organization, cannot avoid some amount of formality in relations, ranks, and roles since Mafia networks, as depicted by Hess, are indeed very flexible, yet also very weak in terms of structure. In fact, in the vast context of transnational activities they would run the risk of proving inadequate and of breaking off more easily (Paoli, 2000: 5-8). Compared to services settled via formal agreements, there is a greater chance that mutual commitments established via informal dyadic agreements cannot or do not want to be honored (Paoli, 2000: 7). Furthermore, in order to guarantee its increasingly diversified activities and interests, the increasingly multifunctional transnational Mafia associations must resort to highly qualified professionals. Nowadays the Mafia cannot do without the professional services of accountants, lawyers, finance and computer experts, chemists, etc. The non-specific advisor, i.e. the old and almost mythical figure of the consigliori, has nearly disappeared or is currently being assisted by a team of specific pros. Therefore, we can say that the Mafia has bureaucratized itself to some extent. Within the network fabric consisting mainly of informal dyadic relations, operations centers with the characteristics of a compact extra-family subsystem involving an aggregate of polyadic relations founded on contracts have taken shape, centering especially around the capimafia. These consolidated cores of the Mafia organizations, as Letizia Paoli has plausibly shown, are based on status contracts vouched for by rituals actions, of which symbolic brotherhood pacts are proof (Paoli, 2000: 77; Weber, 1956: Vol. 2, 416 ff.). These agreements are not set up for temporary or short-term activities; instead, they are marked by their continuance and formal character. Therefore, these social relations have a different quality: more lasting and official compared to other ties within a broader Mafia network. Through status contracts, the members of consolidated nuclei become comrades and develop an esprit du corps, which we 
would have a hard time locating among other network members. Actually, within these relatively small operations centers of the Mafia we can observe a wide range of highly symbolic ritual behaviors that have been overly emphasized and generalized in the folkloristic myth, as shown in the previous chapter. Taking up the example of Andreotti again, we can reasonably presume that he was mixed up in one or more Mafia networks without ever formally belonging to one of the above-mentioned consolidated cores. If this were true, then we would have a plausible explanation for the public prosecutor's nonsuccess at the trial against the former prime minister. For the time being, whether Andreotti's alleged behavior was unintentional or a remarkably well-contrived ploy will still be a shot in the dark.

\section{The Trade Metaphor}

This representation of the Mafia, suggested by Diego Gambetta for Sicily and by Federico Varese for post-communist Russia, is an attempt to reconstruct the rational grounds of Mafia organizations' functioning. Both these authors, who through empirical material confirm the Mafia's decentralized and net-like aspect, set out to prove, thanks to a keen though too universalistic interpretation of the rational choice paradigm, that the social fabric of Mafia criminality shares functional similarities with the industrial enterprises' one. Thus, Mafia associations in the end are firms or at times cartels that produce and manage private protection within the public sphere. To understand Gambetta's and Varese's line of reasoning, yet without being able to delve into all the arguments they developed, we will try to illustrate their interpretation of one of the main functions of psychological pressure, besides threats and duress via the trade metaphor.

Gambetta in particular highlights how the aspects of physical and mental violence, always present in the Mafia's context, may be regarded as a specific marketing scheme (Gambetta, 1992: 43). If a mafioso wants to be considered a competent patron, i.e. if he wants to appear as a successful producer of protection, then he must permanently prove to public opinion that in any given situation he can act resolutely and vigorously. Specifically, the capomafia must therefore be capable of using violence. By using violence he can bolster or, better yet, add to his reputation of uomod'onore, thus drawing new clients in need of private protection. According to Gambetta, the Mafia, as a private protection industry, operates just like an automobile factory in the end. While the latter extols the safety and comfort offered by its automobiles, the Mafia promotes itself by displaying its purveyors' determination (Gambetta, 1992: 43).

However, the question is why should a society and its members need a private protection industry. At this point, Gambetta and Varese introduce a notion that in my opinion is of major importance to understand the Mafia phenomenon in Sicily and elsewhere. It is the concept of trust, which may be regarded as the footing of interpersonal cooperation and - according to NiklasLuhmann's terminology - as a mechanism suited to reduce social complexity (Gambetta, 1988: IX ff.; Luhmann, 1973: 23 ff. and 40). Using the trade metaphor terminology, we can finally say that the Mafia, not being an exclusively Sicilian phenomenon, tenders its products successfully in those societies in which trust, especially public trust, is in very short supply. Supply and demand of Mafia-like private protection occur when there is a widespread feeling of extensive distrust in a given society towards the State's organs and its representatives, as well as towards civil society's institutions.

\section{The Mafia between Historical Legacy and Globalization Processes: A Disenchanted PeRspective}

With great insight, Giovanni Falcone strongly upheld a disenchanted view of the Mafia and associated phenomena (Falcone, 2005: 82 seq.). Through our reconstruction of the different representations of the Mafia propounded by the various branches of social sciences, we have tried to answer the question made by the assassinated public prosecutor of whether or not the need for a disenchanted view has been at least partially taken into account. At first sight, we can certainly reckon that, as previously mentioned, in almost every myth, metaphor, or narrative, beyond misleading overstatements and overhasty or even inaccurate reflections, we can find important and enlightening theoretic references. However, these are always half-truths, which help to understand what we may call the planet Mafia only to a limited extent.

Developing a general theory of Mafia phenomena might be illusory. However, all these interpretative attempts lack a plausible explanation as to whythe Mafia in Sicily, despite quite a strong anti-Mafia 
movement in the Nineties, is still such a vital and strong social fact, and quasi-Mafia organizations in others parts of the world, particularly in post-socialist societies, have gained ground so sensationally.

I believe that Gambetta and Varese, by stressing the importance of trust and respectively distrust in the public sphere, have brought to light a very important track, which to-date has not been fully looked into not even by these two authors. Maybe the too universalistic paradigm of rational choice is not the most suitable theoretic tool to explain the persistence of certain social facts and eventually turned into a trap for the authors themselves. In fact, Gambetta deems the entrepreneurial logic and rationale inherent to Mafia as a general human constant, while public distrust, in which the Mafia persistence is grounded, remains a reality that in effect is beyond specific social or historical contexts. Prior to these two authors, Falcone as well had stressed the crucial consequence of public distrust (specifically towards State institutions) on the Mafia's endurance in modernity:

\section{"I have faith in the State and believe that this lack of sense of State as an interiorized value gives rise to certain distortions within the Sicilian spirit: the dualism between society and State; falling back on the family, the group, the clan..." (Falcone, 2005:71).}

A historical-anthropological view should certainly employ concepts such as trust and distrust. Above all, it cannot settle for a supposition as apodictic as the one formulated by Gambetta modeled on the rational choice paradigm. In fact, this course of action is contextual and not, a priori, general. Even the rise of distrust and a decline of trust are social productions and must therefore be regarded as phenomena that are embedded in history.

History, however, cannot be reduced to a mechanical or automatic sequence of objective facts. Instead, it must be understood as an interpreted past that is activated by the actors themselves in their present to be interpreted (Ricoeur, 1985: Vol. 3, 314). Thus, we reach the core of this chapter; i.e. the question of history as a past that is experienced either in a direct or mediated way and then actualized (Giordano, 2005: 53-71). This concerns what has been defined as the presence or efficacy of history (Schaff, 1976: 129; Ricoeur, 1985: Vol.3, 495). Unlike socio-genetic narratives, the historicalanthropological view doesn't deal as much with the Mafia's sociologically relevant roots but rather with the social construction of continuity, by which Mafia activities in the minds of members of some societies take on and maintain a specific meaning.

The question of the continuity and persistence, in Sicily and elsewhere, of the social fact called Mafia cannot be adequately dealt with neither with a culturalist approach, which usually employs a overly static notion of culture by which the actors are caged in a fixed frame and thus reduced to robots without a choice, nor with a now obsolete biologizing paradigm. According to the historicalanthropological view, the endurance of Mafia phenomena, despite their inevitable socio-structural changes, springs from the tight and permanent interaction between the collective spaces of experience, in the sense of interpreted past, and the horizons of expectation to be considered instead as imagined future (and thus to be interpreted) in the present (Koselleck, 1979: $349 \mathrm{ff}$.).

The current public distrust and the Mafia as an adequate principle of social organization are strictly linked with the dreadful experiences that members of a given society have continuously had with the State, both in a recent and distant past. Obviously, these negatives spaces of experience, which have a marked influence on the actors and the formation of their horizons of expectation, do not reproduce themselves automatically by tradition, i.e. just because they are handed on from generation to generation. Such spaces of experience must be constantly confirmed in the present. Traditions as well as mentalities are extremely moldable phenomena whose plausibility and adequacy must be permanently verified and confirmed. In accordance with the members' perception of these experiences, the corresponding systems of representations and behavior models will be strengthened, modified, or in case discarded.

The reproduction of negative spaces of experience in societies of public distrust, such as the one in the Mezzogiorno or those of Eastern Europe, as already mentioned goes hand in hand with the constant failing of the State and the institutions of civil society. Yet, such a public inability to carry out ones duties is not only an objective fact that can be observed from the outside but, far more important, it is also shared inside and consequently built as such by the citizens themselves. Thus, for the actors affected by the permanent disaster of public powers and associations of the civil society, the persistence, resurgence and expansion of Mafia action models are possible rational responses.

The case of Berlusconi, and specifically his sly and high-handed unwillingness to solve the clash of interests on account of his appointment as prime minister and the concurrent persistence of control 
over several newspapers and magazines and an entire national broadcasting network, is paradigmatic to prove the negative experiences handed down from the past (with their resultant actualization). The Italian Premier's sensational and reprehensible behavior can only confirm the citizen's social representations based on past experiences (and thus those belonging to the cognitive capital grafted on the collective memory). However, according to this social knowledge, the public sphere is the ideal place in which politicians, managers of civil society associations, and public administrators, wheelerdealers and profiteers, can easily grasp material, social, and symbolic resources, securing enormous and utterly personal advantages at the expense of third parties. Through his unwillingness to solve the clash of interests, Berlusconi has definitely strengthened the distrust in everything public, especially if it pertains to the State. Thus, the notion that in the non-strictly private sector (meaning kinship and family) one must depend upon the help and protection of friends, godfathers, patrons and mafiosi, once again has turned out to be the most reliable premise to find ones way about in society in the most suitable manner.

Yet, this example shows that the Mafia -in all those societies where it flourishes- should neither be regarded as a cultural relic nor as an anachronistic anomaly. From a historical-anthropological viewpoint, it is rather a historical legacy whose meaning is constantly confirmed, actualized, and legitimated in the present thanks to a cognitive capital and a social knowledge that are both congruent and shared by most members of a given collectivity.

Finally, we ought to ask ourselves whether the Mafia as a historical legacy has a future in a world undergoing constant globalizing pressures. If we take into account the major theoreticians of globalization, we will notice that overall they stress the importance of the following phenomena:

- The more or less forced transfer of sovereignty and thus of control from the national States to both the global market and localist (or particularistic) organizations (Ong, 1999: 214-217; Misztal, 2000:55),

- The decline of public (or systemic) trust among citizens and the consequent legitimacy crisis of democratic States (Misztal 2000: 51; Castells, 1997: 343-346),

- The growing expansion of informality in human relations and thus the increase of non-public network structures lacking an official character (Meny, 1996: 116; Misztal, 2000: 56),

- The increasing interconnection between political and economic interests (Misztal, 2000: 56-57).

If this scenario is realistic, and it may well be, then it is certainly true, as supposed by a possibly too unilateral sociological view (Ryan, 1983: 150), that the individualization inherent to globalization entails a freedom of choice, a pluralization of world views, and a liberalization of life-styles. However, it is also true that these aspects of the globalization process can forward the emergence or development of clientelism, of corruption, and, consequently, of Mafia and quasi-Mafia activities. In fact, the planet Mafia, due to its net-like, personalized, and informal structure, its ideological representations, alternate to the State's ones, and finally its historically tested functional qualifications to offer private protection in place of the lethargic States, and thus unreliable for the citizens, is not in the least at risk of reaching its end, as PinoArlacchi hypothesized. The risk is that it becomes a criminal global player, which will increasingly challenge the police forces of the entire world.

\section{REFERENCES}

Alongi, Giuseppe, 1887, La maffia nei suoi fattori e nelle sue manifestazioni. Studio sulle classi pericolose della Sicilia., Torino (Bocca)

Blok, Anton, 1974, The mafia of a SicilianVillage, 1860-1960. A Study of Violent Peasant Entrepreneurs, Oxford (Basil Blackwell).

Castells, Manuel, 1997, The Power of Identity, Cambridge (Polity Press).

Cutrera, Antonino, 1900, La mafia ed i mafiosi. Origine e manifestazioni. Studio di Sociologia Criminale, Palermo (Reber Editore).

Falcone, Giovanni, 2005, Cose di Cosa Nostra. Milano (BUR Biblioteca Universale Rizzoli.)

Fava, Giuseppe, 1983, I quattro cavalieri dell'Apocalisse mafiosa, in. I Sciliani 1: 21-41.

Gambetta, Diego, ed., 1988, Trust: Making and Breaking Cooperative Relations, Oxford (Basil Blackwell) 
Gambetta, Diego, 1992, La mafia siciliana. Un'industria della protezione privata, Torino (Einaudi).

Giordano, Christian, 1992, Die Betrogenen der Geschichte. Überlagerungsmentalität und Überlagerungsrationalität in mediterranen Gesellschaften, Frankfurt/M. und New York (Campus Verlag).

Giordano, Christian, 2001, Réseaux mafieux: la gestion de la méfiance publique, in: Le guide 2001 des PME, Supplement de l'AGEFI, Le Quotidien suisse des affaires et de la finance. Lausanne: 44-46.

Giordano, Christian, 2005, The Past in the Present. Actualized History in the Social Construction of Reality, in: Kalb, Don eTak Herman (eds.) Critical Junctions. Anthropology and History beyond the Cultural Turn, Oxford (Berghahn): 53-71.

Hess, Henner, 1988, Mafia. Zentrale Herrschaft und lokale Gegenmacht, Tübingen (J.C.B.

Mohr Verlag, Paul Siebeck).

Heyman, Josiah McC. und Smart, Alan, 1999, States and Illegal Practices: an Overview, in: Heyman, Josiah, McC., Hg., States and Illegal Practices, Oxford und New York (Berg).

Imposimato, Ferdinando, 2000, Un juge en Italie. Pouvoir, Corruption, terrorisme. Les dossiers noirs de la Mafia, Paris (Editions de Fallois)

Kaser, Karl, 1995, Familie und Verwandtschaft auf dem Balkan. Analyse einer untergehenden Kultur, Wien, Köln, Weimar (Böhlau Verlag).

Kaser, Karl, 2001, Freundschaft und Feundschaft auf dem Balkan. Euro-balkanische Herausforderungen. Klagenfurt (Wieser Verlag).

Koselleck, Reinhart, 1979, Vergangene Zukunft. Zur Semantik geschichtlicher Zeiten, Frankfurt/M. (Suhrkamp Verlag).

Luhmann, Niklas, 1973, Vertrauen. Ein Mechanismus der Reduktion von Komplexität, Stuttgart (Ferdinand Enke Verlag).

Mappes-Niediek, Norbert, 2003, Balkan-Mafia. Staaten in der Hand des Verbrechens. Eine Gefahr für Europa, Berlin (Ch. Links Verlag).

Meny, Yves, 1996, Politics, Corruptionand Democracy, in: European Journal of Political Research, 30: 111-123.

Misztal, Barbara, 2000, Informality. Social Theory and Contemporary Practice, London e New York (Routledge)

Mühlmann, Wilhelm E., 1969, Zur Sozialpsychologie der Mafia, in: Kölner Zeitschrift für Soziologie und Sozialpsychologie, 21, 2: 289-303.

Ong, Aihwa, 1999, Flexible Citizenship: The Cultural Logic of Transnationality, Durham, London (Duke University Press).

Paoli, Letizia, 2000, Fratelli di mafia. Cosa Nostra e `Ndrangheta. Bologna (Il Mulino).

Ricoeur, Paul, 1985, Temps et récit, Paris (Editions du Seuil)

Ryan, Alan, 1983, Private Selves and Public Parts, in : Been, S. I. e Gaus, G. F. eds. Public and Private Social Life, London (Croom Hall) :

Schaff, Adam, 1976, Die Präsenz von Geschichte, in: SSIP-Bulletin, 43: 122-131.

Varese, Federico, 2001, The Russian Mafia: Private Protection in a New Market Economy, Oxford (Oxford University Press).

Weber, Max, 1956, Wirtschaft und Gesellschaft, Tübingen, (J.C.B. Mohr Verlag, Paul Siebeck) 